\title{
BOOK REVIEW SECTION
}

Bobic, N.: Balkanization and Global Politics: Remaking Cities and Architecture. London, Routledge. 2019. $228 \mathrm{p}$.

The Balkans form a distinctive unit in people's mental maps, often based on the area's stereotypical sociocultural characteristic. Depending on the context, the word 'Balkanic' can either have negative (fragmentation, division, instability) or positive connotations (inclusivity, coexistence, heterogenity), and all of these can be tied to the conditions (perceived from a Western perspective) of the territory during the turmoils of $20^{\text {th }}$ century geopolitics. These forces led to violent destruction and reconstruction that left a tremendous mark on the physical and cultural landscape of the area, making the region understandable only through the discourses of Balkanism and balkanisation.

Balkanization and Global Politics examines and critically engages with these narratives in an urban and architectural form. The author is an architect by trade who also teaches architecture as a lecturer at the University of Portsmouth. Published as a part of the "Routledge Studies in Urbanism and the City" series in April 2019, the book is a continuation of her research presented in her dissertation written at the University of Sydney, with four segments published

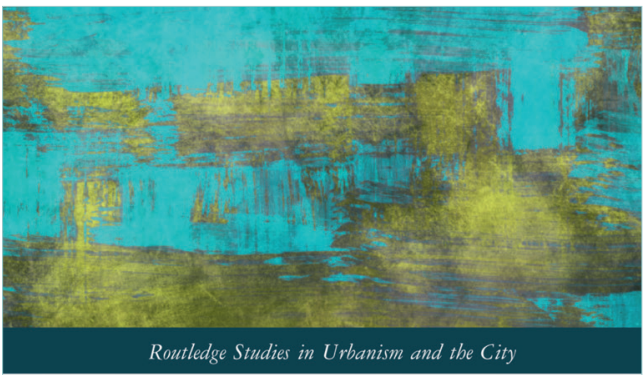

\section{BALKANIZATION AND GLOBAL POLITICS REMAKING CITIES AND ARCHITECTURE}

Nikolina Bobic

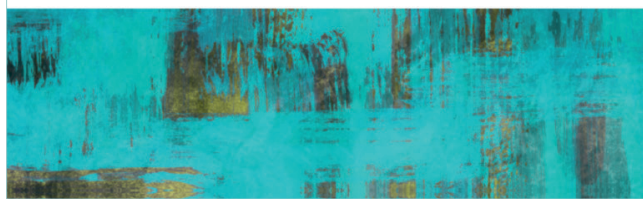

earlier (Boвic, N. 2012, 2014, 2015, 2017), all of which she expanded upon for this manuscript. According to the preface, the most important expansion is the discourse analysis of Balkanism and balkanisation which is detailed in the first two chapters.

Balkanism, with reference to, and contrasted with, Edward SAID's Orientalism (1978), emerged from the position of the region between the imaginary West and East, without being necessarily Occidental or Oriental enough to fit into either category. This term, coined by Maria Todorova (1997), refers to a mode of identification when facing this problem of liminality. Balkanisation started with the events after the withdrawal of the Ottoman Empire from the peninsula in the $19^{\text {th }}$ century and with subsequent aspirations for forming ethnically homogenous nation states in its place. The resulting geopolitical fragmentation became synonymous with the area (hence the name of the term), which in a more metaphorical sense refers to the way of solving a large heterogenic unit's problems by breaking it up into smaller, controllable homogenic parts. This makes it applicable to other scales as well, shifting the meaning of the term with it. One common way of this is creating enclaves of immigrants on the city periphery to maintain order and clear power relations - urban heterotopias (SHANE, D. 1995). Despite encompassing processes stemming from the same context, these two terms have an important difference in their stance toward global dichotomies: while Balkanism is grounded in a transitory and liminal space, the goal of balkanisation is to reorder and remake for the sake of a special form of Westernisation.

From another perspective, this book is about the concept most frequently termed as urbicide, which "refers to the intentional attempt to erase or destroy a city or cities for political purposes" (Graham, S. and Gregory, D. 2009, 794). This line of thought, that arose in the 1970s from the work of architectural critic Ada Louise Huxtable (1970), later popularised for social sciences by Marshall Berman (1996), criticises the perceived consensus of planners about the necessity to modernise cities. The term gained a new dimension during the Yugoslav wars. It was used by architect and former Mayor of Belgrade, Bogdan Bogdanović, referring to the bombing of Croatian cities by the JNA (Yugoslav People's Army), comparing the destruction of UNESCO World Heritage Site Dubrovnik to "a madman who throws acid in a beautiful woman's face and promises her a beautiful face in return" (Bogdanović, B. 1995, 53, quoted by Boвic, 
N. 2019, 58). The difference in this mode of urbicide lies in its methods - instead of hiding the political motives behind the veil of planning, it is conducted through raw military violence.

The author succeeds in interdisciplinarity with her writing, speaking the language of social science, addressing themes, using methods and subscribing to theories not unusual for ethnical, political or cultural geographers and urbanists. BовІс's topics transcend a number of scales, ranging from international context of the geopolitics of balkanisation, but also diving into case studies of a couple of buildings, a level which only in recent decades started to be included in geographical imagination.

After the introduction and the setting of the theoretical framework in Chapter 1, Chapter 2 continues with an extensive discourse analysis of Balkanism and balkanisation, highlighting the differing uses and interpretations across a variety of disciplines ranging from architecture through planning to sociology. Here BовIC uses a two-pronged approach through a global and a local lens simultaneously to emphasise the flexibility and mobility of the term.

Chapter 3 leads us to the detailed story of the Yugoslav wars in the 1990s, from the perspective of the parts of a dissolving country being systematically destroyed and rebuilt to assert control. This is the section that more explicitly deals with the topic of urbicide and its consequences, with Vukovar and Dubrovnik in Croatia, and Sarajevo and Mostar in Bosnia-Herzegovina examined in detail. I would like to mention the clever (and geographically pleasing) title choice of these sections: first the author describes the wartime desctruction calling it "dislocating the countries." Then, after she establishes remaking as falsifying history, we read about the chosen cities' efforts of remembering under the title "locating the countries."

Вовіс introduces a new face of the concept of Balkanism in Chapter 4. It can also be understood as "a process by which certain acts of violence are normalised and/or ennobled as humanitarian, while others are constructed as acts of deep-seated barbarism" (Вовіс, N. 2019, 89). Following this line of thought, she explores the coercive nature of balkanisation during and after the first humanitarian air intervention (1999 Operation Allied Force). Examples are provided as archtitectural and landscape changes from Belgrade.

The discussion of violence continues in the next chapter moving on to less direct, sudden or visible forms of it. These constricting acts of humanitarianism, the contradictions and excess of Balkanism in Kosovo, the uranium radiation and the remaining undetected bombs had even heavier, long-lasting consequences in some cases than the war itself, yet these were reported in Western media in a positive light.

The penultimate chapter introduces a Belgrade case study on how intertwining levels of fragmentation can have different outcomes when entangled with deliberate gentrification in an urban setting, raising questions about the responsibility of planning in effectively desocialising, de-Romanising and homogenising a city catering to the needs of a wealthy minority.

The ideas raised throughout the book are summarised and reflected upon in the last chapter, where the author concludes that balkanisation is a far more complex set of processes than its usual definitions would suggest, and that the liminality of Balkanism predetermines its fluidity and mobility both geographically and conceptually. This conclusion prompts a peak outside of the Balkans as well, providing recent examples of these processes from other parts of the world. Brexit signified a possible start of balkanisation inside the EU, and with smaller ethnically homogenous enclaves like Catalonia, Northern Italy, Szeklerland or Scotland (as a special case of Brexit), looking to expand their current level of autonomy, the process might bear new countries in the future as well, populist politicians are certainly looking to exploit the associated feelings of "power in homogeneity" like they did before. The last paragraphs explain how the migration crisis (and international migration in general for decades) effected the Balkans and the world's ongoing forms of balkanisation on all scales from local planning to global geopolitics, with the area being in the traditional transit zone for (mostly) Middle Eastern immigrants travelling to Western Europe.

Bовіc's book deals with subjects that I find deeply geographical and its critical tone resonates well with that. It provides a detailed analysis of the concepts of Balkanism and balkanisation and contains several illuminating case studies from the intersections of urbanism, planning and architecture. Therefore, I believe it would be a good introductory text even for geographers approaching the topic for the first time, but at the same time it also proves useful for academics researching the Balkans for decades.

Botond PALACZKi ${ }^{1}$

\section{REFERENCES}

Berman, M. 1996. Falling towers: city life after urbicide. In Geography and Identity. Ed.: Crow, D., Washington DC, Maisonneuve Press. 172-192.

Bовіс, N. 2012. Belgrade in formation(s): Dobrovic's Generalstab Complex. Fabrications 21. (1): 6-27.

Вовіс, N. 2014. New Belgrade after 1999: Spatial violence as de-socialisation, de-Romanisation, and de-historisation. Architectural Theory Review 19. (3): 355-375.

${ }^{1}$ Institute for Sociology, Centre for Social Sciences, ELKH, Budapest, Hungary.

E-mail: palaczki.botond@tk.mta.hu. 
Bовіс, N. 2015. War machine: Media and technology during Operation Allied Force. Fabrications 25. (3): 398-416.

BовIC, N. 2017. Belgrade (de)void of identity: Politics of time, politics of control, politics of difference. Cultural Dynamics 29. (1-2): 3-22.

Bogdanović, B. 1995. The city and death. In Balkan Blues: Writing Out of Yugoslavia. Ed.: LABon, J., Evanston, Northwestern University Press. 37-74.

Graham, S. and Gregory, D. 2009. Urbicide. In The Dictionary of Human Geography. Eds.: Gregory, D., Johnston, R., Pratt, G., Watts, M. and Whatmore, S., Malden, Blackwell.
Huxtable, A.L. 1970. Will They Ever Finish Bruckner Boulevard? Berkeley, University of California Press. SAID, E. W. 1978. Orientalism. New York, Pantheon Books.

Shane, D. 1995. Balkanization and the postmodern city. In Mortal City. Ed.: LANG, P., New York, Princeton Architectural Press. 154-169.

Todorova, M. 1997. Imagining the Balkans. New York, Oxford University Press. 